\title{
THE RELATIONSHIP BETWEEN BASELINE CD4 T CELLS' LEVEL AND RECOVERY RATE AFTER INITIATION OF ART IN HIV/AIDS INFECTED AT HOSPITAL FOR TROPICAL DISEASES, VIETNAM
}

\author{
TAO GIA PHU*, HUYNH THI HONG NHUNG \\ Department of Medicine and Pharmacy, Tra Vinh University, Tra Vinh City, Viet Nam. Email: tgphu@tvu.edu.vn \\ Received: 19 May 2020, Revised and Accepted: 14 July 2020
}

\begin{abstract}
Objective: HIV/AIDS pandemic continues to be a public health problem in developing countries. This study aimed to assess the correlation of recovery responses and baseline CD4 T cells' level in HIV/AIDS adult patients after initiation of antiretroviral therapy (ART) in Vietnam.

Methods: The study was a clinic-based longitudinal study done at an outpatient clinic, Tropical Diseases Hospital, Ho Chi Minh City, Vietnam, from $10 / 2018$ to $8 / 2019$.

Results: Ninety-three patients were provided informed consent to participate in this study. Overall, the mean of CD4 T cell counts was 161.7 cells/ $\mu$ l. In AIDS patients groups, at the baseline mean of T CD4 cell was 65 cells/ $\mu$ l and in the non-AIDS group was 315 cells/ $\mu$ l. The slope of the plotted overall CD4 cell counts increased significantly in both two groups and the steepest increases in the first 3 months. After 6 months, patients who were AIDS stages were had a higher viral load in plasma than others, with $\mathrm{p}<0.005$. The changes in CD 4 T cell counts were significantly associated with age and occupational status.
\end{abstract}

Conclusion: The present study found that immunological responses of patients with first-line ART were not related to baseline CD4 T cells' level. However, low baseline CD4 counts were associated with poor virologic suppression.

Keywords: HIV/AIDS, Antiretroviral therapy, CD4 T cell.

(C) 2020 The Authors. Published by Innovare Academic Sciences Pvt Ltd. This is an open access article under the CC BY license (http://creativecommons. org/licenses/by/4. 0/) DOI: http://dx.doi.org/10.22159/ajpcr.2020.v13i10.38383

\section{INTRODUCTION}

HIV/AIDS pandemic is still a serious public health problem in developing countries with a high incidence and high mortality rate [1]. No vaccine has been found for this disease until now. However, with the appearance of effective antiretroviral therapy (ART), nowadays, HIV infected patients could prolong their lives with the ART which is effective in improving the amount of CD4 T cells [2]. Whereas, T lymphocyte level remains the foremost important and most typically used marker for monitoring of the immune status of HIV infected individuals. It is also used for staging the disease and provision of additional essential information for the clinical management of HIV infected patients [24]. However, the clinical and immunological responses among patients in AIDS stages and others are mixed. Some studies have shown that recovery response is strongly related to baseline CD4 count $[5,6]$. Many researches have shown that patients with lower baseline CD4 are recovery worse [7-9]. While some studies have shown that there is no major difference in recovery response between the AIDS and non-AIDS groups [10].

Measurement of the early response within the first 6 months of therapy was important to ART [11]. Due to the advantage of early detection and therapy, this study aimed to assess the correlation of recovery responses and baseline CD4 T cells' level in HIV/AIDS adult patients after initiation of ART in Tropical Diseases Hospital in Ho Chi Minh City, Vietnam.

\section{METHODS}

\section{Study design}

This was a clinic-based longitudinal study done at the outpatient clinic, Tropical Diseases Hospital, from 2018 to 2019.
Study setting

The study was conducted at an outpatient clinic, Tropical Diseases Hospital, Ho Chi Minh City, Vietnam. Tropical Diseases Hospital is a researching and teaching hospital for medical students in southern of Vietnam.

\section{Study participants}

The study involved adult HIV-infected patients aged 18 and above who enrolled in HIV care and initiated on first-line ART, with a minimum follow-up of 6 months.

\section{Data collection and laboratory analysis}

The adult HIV patients on first-line ART with a minimum follow-up of 6 months were invited to participate in this study. These patients are usually followed up monthly or after every 3 months, depending on their clinical status. TCD4 measurements are usually routinely performed after every 3 months. After giving consent, a structured questionnaire was used to collect information regarding epidemic data, date of diagnosis of HIV, date of ART initiation and regime, compliance level, which was assessed using patient response method, body mass index, comorbidities, co-medications, TCD4, viral load, and others routine laboratory.

AIDS stages defined (based on the World Health Organization criteria for the immunological stage): HIV patients who had CD4 cell counts of below 200 cells/ $\mu \mathrm{l}[12]$.

\section{Statistical analysis}

The data were entered, verified, and cleaned using EpiData spread, and the data analysis was done using STATA. Continuous variables were 
summarized by medians and interquartile ranges, and categorical variables were summarized by frequency and percentage.

\section{Consent to participate}

The consent to participate in the study was taken from all study participants because the study only recorded patients who provided written consent. All patients with immunological failure were switched into the second line of ART following the failure of improvement of their TCD4 2 weeks of intensified adherence and in some with virological proof of ART treatment failure as per existing treatment guidelines. Patients who declined consent were not denied their services (the study was approved by the Human Research Ethics Committee of the Hospital for Tropical Diseases in Ho Chi Minh City, dated 18-10-2018).

\section{RESULTS}

A total of 93 patients were provided informed consent to participate in this study. The median age was 30 (26-39); most of the participants were male. Overall, the mean of CD4 T cell counts was 161.7 cells $/ \mu$ l. In the AIDS patients group, at baseline mean of T CD 4 cells was 65 cells $/ \mu \mathrm{l}$ and in non-AIDS patients group was 315 cells/ $\mu$ l that shows in Table 1.

An analysis of the 6-month increase in CD4 cell counts demonstrated that the slope of the plotted overall CD4 cell counts increased significantly in both two groups (with $\mathrm{p}<0.05$ ) and the steepest increases in the first 3 months that shows in Table 2.

In the study, after 6 months, the result showed that virological response was likely to not difference in two groups of patients who were AIDS stages and others. However, the 6-month changes in the viral load after the commencement of treatment were significantly different in the two

Table 1: Mean of baseline TCD4 cell counts $(n=93)$

\begin{tabular}{lll}
\hline Baseline CD4 count & $\begin{array}{l}\text { Mean of TCD4 cell } \\
\text { counts }(\text { cells } / \boldsymbol{\mu l})\end{array}$ & $\begin{array}{l}\text { Percentage and } \\
\text { frequency } \% /(\mathbf{n})\end{array}$ \\
\hline TCD $4<200($ cells $/ \mu \mathrm{l})$ & 65 & $61.3(57)$ \\
TCD4 $\geq 200($ cells $/ \mu \mathrm{l})$ & 315 & $38.7(36)$ \\
Total & 161.7 & $100(93)$ \\
\hline
\end{tabular}

Table 2: Mean of CD4 T cell counts before and after week 12

\begin{tabular}{lllll}
\hline Variable & 0 month & 3 months & 6 months & p value* \\
\hline Baseline TCD4 & 64.9 & 227.3 & 257.1 & $\mathrm{p} 1<0.001$ \\
$<200$ cells $/ \mu \mathrm{l}$ & $(57.3)$ & $(134.2)$ & $(133.3)$ & $\mathrm{p} 2<0.001$ \\
& & & & $\mathrm{p} 3=0.009$ \\
Baseline TCD4 & 314.9 & 478.9 & 573.9 & $\mathrm{p} 1<0.001$ \\
$\geq 200$ cells $/ \mu \mathrm{l}$ & $(39.7)$ & $(160.1)$ & $(207.4)$ & $\mathrm{p} 2<0.001$ \\
& & & & $\mathrm{p} 3<0.001$ \\
\hline
\end{tabular}

*Wilcoxon signed-rank test. p1, p2: At point 3 months and 6 months compared to the original; p3: At 6 months compared to 3 months

Table 3: Comparison outcomes following the use of ART among AIDS patients and other HIV patients

\begin{tabular}{|c|c|c|c|}
\hline Variables & $\begin{array}{l}\text { Baseline TCD4 } \\
<200 \text { cells } / \mu l\end{array}$ & $\begin{array}{l}\text { Baseline TCD4 } \\
\geq 200 \text { cells } / \mu \mathrm{l}\end{array}$ & p value \\
\hline \multicolumn{4}{|c|}{ Virological response at 6 months (frequency/percentage) } \\
\hline Virological success & $56(98.2)$ & $-33(91.7)$ & $\mathrm{p}=0.1^{*}$ \\
\hline Virological failure & $1(1.8)$ & $-\quad 3(8.3)$ & \\
\hline \multicolumn{4}{|c|}{ Viral load at 6 months (frequency/percentage) } \\
\hline$<20 \mathrm{cps} / \mu \mathrm{l}$ & $42(73.7)$ & $-33(91.7)$ & $\mathrm{p}=0.03^{*}$ \\
\hline$\geq 20 \mathrm{cps} / \mu \mathrm{l}$ & $15(26.3)$ & $-\quad 3(8.3)$ & \\
\hline
\end{tabular}

groups. Patients who were AIDS stages were had a high viral load in plasma than non-AIDS stages, with $\mathrm{p}<0.005$ that shows in Table 3 .

The changes in CD4 lymphocyte count in the study on the $3^{\text {rd }}$ month were significantly associated with the age of patients (immunity recovery in young patients was faster than older). In the $6^{\text {th }}$ month, the changes in CD4 lymphocyte count were significantly associated with occupational status (have employed) (Table 4).

\section{DISCUSSION}

This retrospective study was carried out to assess the trends in immunology and virological recovery among HIV patients after the initiation of ART and also the effect of baseline characteristics on CD4 cell counts response. After the beginning of suppressive ART in an immunosuppressed HIV-infected person, the increase in CD4 T-cell counts characteristically exhibits a biphasic pattern. A steep initial phase likely reflects the redistribution of cells from lymphoid tissue over the first few months of treatment as suppression of viral replication reduces immune activation [13]. Improvements in overall CD4 cell counts among the patients were seen overtime after 6 months. These findings are according to the retrospective longitudinal study conducted in Uganda in which the median CD4 lymphocyte count was found improving over time [14]. Other studies in the U.S showed that the median CD4 cell counts continued to rise even up to 10 years after ART initiation, with the steepest increase in the first 3 months [15]. Similarly, many studies also clearly investigated that CD4 cell counts increased significantly after 6 months of the initiation of ART [14,16-18]. On the other hand, immunologically and virological response was likely to not different in two groups of patients who were AIDS stages and others. Similar findings in the North of Vietnam have also been reported by other authors that immunity recovery was not associated with baseline CD4 T cells' level of patients [19]. Although not completely likely, some studies which were conducted from Ethiopia and China supported our result that immunity recovery in ART was dependent on baseline CD4 T cells $[10,20]$.

Although no significant difference was observed in baseline CD4 counts and virological response during this study, viral loads in plasma were a significant difference between the two groups of patients. Viral load and CD4 cell counts are well established prognostic markers of HIV disease progression; however, some uncertainties remain over the speed of change of viral load before starting ART and also the relationship with baseline CD4 $\mathrm{T}$ cell counts [21]. In addition, several studies have demonstrated that baseline CD4 counts play important roles in predicting outcomes in viral loads [21,22]. At the identical time, higher in baseline CD4 counts that may lead to suppression of HIV better and also improves outcomes of viral load in plasma [21]. However, to extend the credibility of the conclusion, further studies are recommended.

In the present study, the factors that pose a positive effect on CD4 recovery rate include: Younger baseline age and have employed status. Younger patients appeared capable of rebuilding their immune systems faster than those aged older [19]. Previous studies have often categorized age to differentiate older patients, where older age usually resulted in slower recovery $[14,15,23]$. This will be explained by decreasing thymic volume with increasing age. Whereas, another factor related to immunological response included occupational status (have employed) may belong to the characteristics and adherence of patients. The results of this study give information that most participants had after treatment with antiretroviral drugs, which has been shown to be effective in improving the quantity CD4 T cells [24,25]. However, the limitation of this study is that it was based on a single clinic; therefore, the results may be not generalizable. 
Table 4: Factor association with TCD4 count change $(n=93)$

\begin{tabular}{|c|c|c|c|c|}
\hline Characteristics & CD4 count at 3 months (Mean \pm SD) & p value & CD4 count at 6 months $($ Mean \pm SD) & p value \\
\hline \multirow[t]{2}{*}{ Age } & - & $\mathrm{r}=-0.2^{3}$ & - & $r=-0.1^{3}$ \\
\hline & & $\mathrm{p}=0.04$ & & $\mathrm{p}=0.1$ \\
\hline \multicolumn{5}{|l|}{ Gender } \\
\hline Male & $329.5 \pm 21.3$ & \multirow[t]{2}{*}{$0.6^{1}$} & $379.9 \pm 224.6$ & \multirow[t]{2}{*}{$0.5^{1}$} \\
\hline Female & $299.5 \pm 51.7$ & & $378.2 \pm 243.7$ & \\
\hline \multicolumn{5}{|l|}{ Educational level } \\
\hline Primary & $482.2 \pm 165.8$ & \multirow[t]{4}{*}{$0.08^{2}$} & $459.2 \pm 151.9$ & \multirow[t]{4}{*}{$0.07^{2}$} \\
\hline High school & $250.7 \pm 30.0$ & & $295.4 \pm 36.4$ & \\
\hline Tertiary & $337.2 \pm 24.9$ & & $412.3 \pm 33.0$ & \\
\hline Above tertiary & $180.5 \pm 56.6$ & & $194.3 \pm 65.5$ & \\
\hline \multicolumn{5}{|l|}{ Marital status } \\
\hline Single & $319.9 \pm 31.1$ & \multirow[t]{4}{*}{$0.9^{2}$} & $345.3 \pm 34.1$ & \multirow[t]{4}{*}{$0,6^{2}$} \\
\hline Married & $328.6 \pm 46.0$ & & $400.2 \pm 54.2$ & \\
\hline Divorce & $332.8 \pm 33.4$ & & $417.9 \pm 42.8$ & \\
\hline Widow & $273.0 \pm 56.8$ & & $270.7 \pm 25.3$ & \\
\hline \multicolumn{5}{|c|}{ Have religious beliefs } \\
\hline Yes & $319.3 \pm 22.8$ & \multirow[t]{2}{*}{$0.5^{2}$} & $367.0 \pm 25.4$ & \multirow[t]{2}{*}{$0.2^{2}$} \\
\hline No & $363.5 \pm 49.0$ & & $457.1 \pm 66.6$ & \\
\hline \multicolumn{5}{|l|}{ Occupational status } \\
\hline Have employed & $337.4(22,4)$ & \multirow[t]{2}{*}{$0.08^{2}$} & $414.7 \pm 28.8$ & \multirow[t]{2}{*}{$0.009^{2}$} \\
\hline Unemployed & $254.9(47.6)$ & & $241.8 \pm 29.3$ & \\
\hline \multicolumn{5}{|l|}{ BMI } \\
\hline$<18.5$ & $291.7 \pm 35.6$ & \multirow[t]{3}{*}{$0.6^{2}$} & $328.9 \pm 44.0$ & \multirow[t]{3}{*}{$0.4^{2}$} \\
\hline $18.5-23.0$ & $331.9 \pm 26.2$ & & $394.4 \pm 29.7$ & \\
\hline$>23.0$ & $354.7 \pm 53.3$ & & $409.2 \pm 73.7$ & \\
\hline \multicolumn{5}{|c|}{ Co-infection hepatitis B } \\
\hline Yes & $317.6 \pm 71.4$ & \multirow[t]{2}{*}{$0.4^{1}$} & $378.0 \pm 90.4$ & \multirow[t]{2}{*}{$0.4^{1}$} \\
\hline No & $325.5 \pm 20.5$ & & $380.0 \pm 24.3$ & \\
\hline \multicolumn{5}{|c|}{ Co-infection hepatitis C } \\
\hline Yes & $158.0 \pm 0.0$ & \multirow[t]{2}{*}{$0.2^{1}$} & $185.0 \pm 0.0$ & \multirow[t]{2}{*}{$0.1^{1}$} \\
\hline No & $326.5 \pm 19.8$ & & $381.8 \pm 23.6$ & \\
\hline
\end{tabular}

${ }^{1}$ Wilcoxon signed-rank test; ${ }^{2}$ Kruskal-Wallis rank test; ${ }^{3}$ Spearman's rank correlation coefficient

\section{CONCLUSION}

The present study found that immunological responses to patients with first-line ART were not related to baseline CD4 T cells' level. However, low baseline CD4 count at the entry to an ART program had virologic response recovery worse. Furthermore, the findings of this study confirm the previous studies that early immune recovery is more common among younger patients than the older, and patients have employed were associated with better immunity responses.

\section{ACKNOWLEDGMENTS}

We would like to thank our colleagues from Tra Vinh University and the University of Medicine and Pharmacy at Ho Chi Minh City who provided insight and expertise that greatly assisted the research. We are also deeply grateful to the patients and staff at the Hospital for Tropical Diseases in Ho Chi Minh City.

\section{AUTHORS' CONTRIBUTIONS}

All the authors contributed equally in preparation of manuscript.

\section{CONFLICTS OF INTEREST}

The authors declare no conflicts of interest in this research.

\section{AUTHORS' FUNDING}

The authors did not receive any funding for this work.

\section{REFERENCES}

1. UNAIDS. Global Summary of the AIDS Epidemic. Geneva: UNAIDS; 2016.

2. World Health Organization. Update of Recommendations on First and Second-line Antiretroviral Regimens. Geneva: World Health
Organization; 2019.

3. Daniel WG, Benson RK, Mshana SE. Accuracy of WHO immunological criteria in identifying virological failure among HIV-infected adults on first line antiretroviral therapy in Mwanza, North-Western Tanzania. BMC Res Notes 2017;10:45.

4. World Health Organization. HIV Drug Resistance Report. Geneva: World Health Organization; 2012.

5. Fengdi Z, Meiyan S, Jianjun S, Guan L, Wang J, Lu H. The risk factors for suboptimal CD4 recovery in HIV infected population: An observational and retrospective study in Shanghai, China. Biosci Trends 2015;9:335-41.

6. Serawit D, Alemayehu T, Fiker T. Pattern and predictors of cluster of differentiation 4 cell count recovery among cohorts of human immunodeficiency virus-infected patients on antiretroviral therapy in Hawassa university referral hospital. J AIDS HIV Res 2018;10:40-8.

7. Olubusuyi MA, Georgina NO, Olaleyea OD. Baseline CD4 T cell level predicts recovery rate after initiation of antiretroviral therapy in HIV infected Nigerians. J Immunoassay Immunochem 2015;37:109-18.

8. Hailay AG, Paul W, Kifle W, Mwanri L. Immunological failure in HIV-infected adults from 2003 to 2015 in Southwest Ethiopia: A retrospective cohort study. BMJ Open 2018;8:e017413.

9. Kesetebirhan DY, Susan H. Prevalence and predictors of immunological failure among HIV patients on HAART in Southern Ethiopia. PLoS One 2015;10:e0125826.

10. Addisu A, Dagim A, Tadele E. CD4 cell count trends after commencement of antiretroviral therapy among HIV infected patients in Tigray, Northern Ethiopia: A retrospective cross-sectional study. PLoS One 2015;10:e122583.

11. World Health Organization. HIV Drug Resistance Early Warning Indicators. Geneva: World Health Organization; 2011.

12. World Health Organization. HIV/AIDS Program Highlights. Geneva: World Health Organization, UNAIDS; 2006.

13. Diaz M, Douek DC, Valdez H, Hill BJ, Peterson D, Sanne I, et al. T cells containing $\mathrm{T}$ cell receptor excision circles are inversely related to HIV replication and are selectively and rapidly released into circulation with antiretroviral treatment. AIDS 2004;17:1145-9.

14. Steve K, Jean N, Anna F, Mukasa B, Montaner JS, Ford N, et al. CD4 T 
cell recovery after initiation of antiretroviral therapy in a resource-limited setting: A prospective cohort analysis. Antivir Ther 2014;19:31-9.

15. Johnathon DB, Sarah DS, Tina C. CD4 count recovery after initiation of antiretroviral therapy in patients infected with human immunodeficiency virus. Am J Med Sci 2016;352:239-44.

16. Ronald JB, Rui W, Florin V. Changes in the slope of the CD4 cell count increase after initiation of potent antiretroviral treatment. J Acquir Immune Defic Syndr 2006;43:433-5.

17. Kroeze S, Ondoa P, Kityo CM, Siwale M, Akanmu S, Wellington M, et al. Suboptimal immune recovery during antiretroviral therapy with sustained HIV suppression in Sub-Saharan Africa. AIDS 2018;32:1043-51.

18. Wondu T, Ambachew T. Detection of immunological treatment failure among HIV infected patients in Ethiopia: A retrospective cohort study. BMC Immunol 2015;16:55.

19. Junko T, Shoko M, Sebastien H. Long-term viral suppression and immune recovery during first-line antiretroviral therapy: A study of an HIV-infected adult cohort in Hanoi, Vietnam. J Int AIDS Soc 2017;20:e25030.

20. Jian W, Biyan L, Xiaoping Z. An 84-month observational study of the changes in CD4 T-lymphocyte cell count of 110 HIV/AIDS patients treated with traditional Chinese medicine. Front Med 2014;8:362-7.

21. The Collaboration of Observational HIV Epidemiological Research Europe. Actors associated with short-term changes in HIV viral load and CD4R cell count in antiretroviral-naive individual. AIDS 2014;28:1351-6.

22. Ingole N, Mehta P, Pazare A. Performance of immunological response in predicting virological failure. AIDS Res Hum Retroviruses 2013;29:541-6.

23. Mpondo CT, Daniel WG, Semvua BK, Mgina E. Immunological and clinical responses following the use of antiretroviral therapy among elderly HIV-infected individuals attending care and treatment clinic in Northwestern Tanzania: A retrospective cohort study. J Sex Transm Dis 2016;2016:5235269.

24. Somshankar D, Mahesh D. Simultaneous estimation of lamivudine, abacavir and dolutegravir by UPLC method. Int $\mathrm{J}$ App Pharm 2018;10:46-52.

25. Emmanuel IO, Nkiruka RU, Ofia AK. Assessment of kidney function, estimated glomerular filtration rate and body mass index in HIV seropositive subjects on antiretroviral therapy in Nnewi. Int J Pharm Pharm Sci 2018;10:44-9. 